\title{
Attitudes towards Gay and Lesbian Parental Rights among Heterosexual Croatian Citizens: The Effect of Traditional Gender-Role Attitudes
}

DOI: $10.5613 /$ rzs.49.2.5

UDK: 316.644-055.32(497.5):316.362.34

Izvorni znanstveni rad

Primljeno: 18. 4. 2019.

\author{
Željka KAMENOV ๑, Aleksandra HUIĆ $\odot$, Margareta JELIĆ \\ Department of Psychology, Faculty of Humanities and Social Sciences, University \\ of Zagreb, Croatia \\ zkamenov@ffzg.hr, ahuic@ffzg.hr, mjelic@ffzg.hr
}

\section{ABSTRACT}

Non-normative sexual orientations question the binary and hierarchically organised image of men-women relations. The main goal of this research was to explore the role of gender identity and gender-roles attitudes in predicting attitudes towards same-sex parenting. An additional goal was to assess whether socio-demographic variables such as age, education, religiosity and political preferences - which proved to be relevant in predicting homonegativity - would also predict attitudes towards same-sex parenting. Finally, the authors explored whether gender identity and gender-role attitudes bore an effect on attitudes towards same-sex parenting after controlling for the socio-demographic variables. An online survey with 992 heterosexual participants of both genders $(70 \%$ women) aged 18 to 79 years was conducted in Croatia in 2014. Participants expressed less support for gay than for lesbian parenting, with female participants expressing more positive attitudes towards both gay and lesbian parenting than male ones. Expectedly, same-sex parenting was more supported by less religious and politically more leftoriented participants, as well as those who cohabitate compared to married participants. Age and education, but also gender identity, did not prove predictive. However, the expectations about the role of traditional gender norms were confirmed. Participants with more traditional gender-role attitudes, as well as those who are parents themselves, expressed more negative attitudes towards same-sex parenting.

Keywords: attitudes towards gay and lesbian parental rights, gender identity, genderrole attitudes, Croatian citizens, socio-demographic characteristics 


\section{INTRODUCTION}

Since December 2013, when a popular referendum on the constitutional definition of marriage was held in Croatia and highlighted the two opposite ways Croatian citizens thought about sexual minorities and their rights, some progress has been made in the formal legal acts that regulate the status of lesbian, gay and bisexual (LGB) persons in Croatia. The enactment of the anti-discrimination legislation, particularly the Same-Sex Life Partnership Act (2014), was an exceptionally important step, as it finally created a legal framework that the state institutions must follow. It can certainly be said that formal legal norms in contemporary Croatian society recognise and accept LGB persons as full citizens and allow them to enjoy most of the rights available to heterosexual citizens. However, the notable exception is the right of same-sex couples to provide foster care or adopt children, which has recently evoked a large public debate. During this debate, it became obvious that a significant number of Croatian citizens are still willing to discriminate against others based on their sexual orientation (Ljubičić, 2015).

These public debates brought the issues of gay and lesbian civil rights to the forefront of scientific interest. Until recently, Croatian researches were mostly interested in the determinants of general attitudes towards gays and lesbians, while research on attitudes towards their civil rights remained neglected. To the best of our knowledge, our earlier study (Huić, Jugović and Kamenov, 2015), in which we investigated the attitudes of university students, was one of the first studies aimed at investigating attitudes towards gay and lesbian civil rights in Croatia. The study was conducted at the time when the Same-Sex Life Partnership Act was being prepared. A total of 1551 heterosexual students from the Universities of Zagreb, Rijeka, Split, and Osijek participated in the study. The results showed that students held the most favourable attitudes towards gay and lesbian employment rights and the right to get information about their same-sex partners in hospital. They supported gay and lesbian marriage, child adoption and assisted reproductive technology use to a lesser extent. The study showed that even university students, who are presumed to represent the most liberal and tolerant, well-educated part of a society (Gelbal and Duyan, 2006; Jäckle and Wenzelburger, 2015), had different opinions about various civil rights and that they had some reservations about giving LGB persons the same rights enjoyed by heterosexual ones. These reservations were most expressed concerning the marital and parental rights of gays and lesbians. A recent public debate on not allowing adoption to same-sex couples together with the findings from our abovementioned study motivated us to conduct an online survey in order to explore the determinants of attitudes of Croatian citizens towards gay and lesbian rights to become parents. 
The vast body of empirical studies conducted in the United States and Europe, as well as in Croatia, shows that socio-demographic characteristics are important predictors of attitudes towards gays and lesbians (e.g. Herek and McLemore, 2013). More negative attitudes are held by men, particularly towards gay men (Herek, 2002; Huić, Jelić and Kamenov, 2018; Huić, Jugović and Kamenov, 2015; Kite and Whitley, 1996; LaMar and Kite, 1998). Attitudes towards gay men and lesbian women are also associated with age, with older persons holding more negative attitudes than younger ones (Avery et al., 2007). Persons with a lower level of formal education also tend to have more negative attitudes (Grapes, 2006; Herek, 1984; Ohlander, Batalova and Treas, 2005). The finding of religiosity being a predictor of negative attitudes towards gays and lesbians has been confirmed in many studies (Gelbal and Duyan, 2006; Herek, 1988; Huić, Jugović and Kamenov, 2015; Jugović and Ančić, 2013; Olson, Cadge and Harrison, 2006; Whitley, 2009). Political orientation also proved to be a significant determinant. More politically conservative individuals hold more negative attitudes towards gays and lesbians than those with a more liberal political orientation. Similarly, the former are also less likely to support the rights of homosexual persons (Brewer, 2003; Wood and Bartkowski, 2004).

It is reasonable to expect that these socio-demographic characteristics would also be important determinants of peoples' attitudes on gay and lesbian parental rights. We could presume that people who are more prone to negative attitudes towards someone based on his or her sexual orientation would also show more negative attitudes towards same-sex parenting. However, should it be the case? Could it be instead that this specific object of attitudes, that involves child care and family issues, is only related to some of these characteristics as well as to some other socio-demographic characteristics that are not relevant to the overall attitude towards homosexual people? Based on the previous studies which have shown that people's marital and parental status reflect their values and orientations as well as different life experiences (Adamczyk and Pitt, 2009; Jäckle and Wenzelburger, 2015), we hypothesised that marital and parental status could be relevant characteristics for attitudes towards someone's parental rights. For this reason, we included marital and parental status in the socio-demographic characteristics considered in this study.

Furthermore, previous studies have partially considered some of the socio-demographic characteristics that have been shown to correlate with attitudes towards gays and lesbians (e.g. Avery et al., 2007; Herek, 2002; Grapes, 2006; Kite and Whitley, 1996; Ohlander, Batalova and Treas, 2005; Whitley, 2009). We wanted to simultaneously test the predictive value of gender, age, education, religiosity, and political orientation, as well as marital and parental status, in explaining atti- 
tudes towards gay and lesbian parenting. A simultaneous test of the relevance of all these socio-demographic characteristics would help fill the gap in the existing research and control for their mutual connections and overlap. For example, when their concomitant contribution to the models of attitudes towards homosexual persons was considered, lower religiosity and a higher level of political liberalism have proven to be more important predictors than age and education (Schwartz, 2010).

In exploring the determinants of attitudes towards same-sex couples' parental rights, all these socio-demographic variables should be considered and addressed. However, our main interest was to explore the role of the two variables relevant to attitudes regarding the appropriate roles, rights, and responsibilities of men and women in society (the gender ideology) - gender identification and gender-role attitudes.

Social identification, defined as the positive emotional valuation of the relationship between self and in-group, also applies to one's identification with his or her gender (Turner et al., 1987). As postulated by the Self-Investment Model (Leach et al., 2008), individuals could differ in the level of their gender identification and feel various amounts of solidarity with other members of their gender, satisfaction with being a man or a woman and centrality of gender identity in their life. In other words, some people identify more with their gender and it is more important to them to behave in a way that is expected from members of their group. Our social identity contributes to our self-esteem and our relationships with in-groups as well as with people we perceive as out-groups. More specifically, it affects the way we feel about people that stand out from our in-group and do not behave according to unwritten group norms and expectations. In the case of gender identity, that applies to persons of the same gender but with non-normative sexual orientations, such as homosexual or bisexual people (Davies, 2004; Kite and Deaux, 1987; Reese, Steffens and Jonas, 2013). Therefore, it is reasonable to expect that men and women who identify more with their gender would be more critical towards their in-group members who violate gender norms and would be less inclined to allow them the same rights that are allowed to "typical" men and women. It can be expected that the most denied right would be the right to become parents because of the fear that they would be wrong role-models and raise children confused with their own gender identity that would further violate gender norms (Baiocco and loverno, 2016).

Although no disadvantages were found for children raised by same-sex parents compared to those raised by different-gender parents (e.g. Crowl, Ahn and Baker, 2008; Patterson, 2005; Vučković Juroš, 2017), negative attitudes towards samesex parenting are often justified by the notion that children need both a mother and a father in order to grow up as fully functional and healthy individuals (e.g. Hicks, 
2008; Webb and Chonody, 2014). Therefore, traditional attitudes towards gender roles may contribute to prejudice towards sexual minorities and stalling same-sex couples' parental rights (Davies, 2004; Webb, Chonody and Kavanagh, 2017; Whitley, 2001). According to the social role theory (Eagly, 1987), gender norms (that are determined by biological sex and power differentials) create certain expectations about the roles, responsibilities, and behaviours of men and women that otherwise have no biological justification. In heterosexual couples, the division of responsibilities has been traditionally demarcated along gender roles based on biological sex (Bartolac, Kamenov and Petrak, 2011). Same-sex couples violate this gendered structure within the family and face more prejudice, especially individuals who demonstrate cross-gender compared to gender-typical behaviours (Lehavot and Lambert, 2007). These perceptions of gender role "violations" may play a role in those opposed to same-sex parental rights. That is, the belief that children need to be raised by both a male and a female role model may be based on traditional beliefs about gender norms, and, in turn, these beliefs may be inhibiting acceptance. In contemporary Croatian society, different public initiatives were aimed at promoting the importance of "traditional family values", perpetuating gender norms within the family and supporting the belief that same-sex couples are incapable of providing equivalent and necessary care to children as heterosexual couples (e.g. ILGA Europe, 2019; Šurina, 2012).

\section{AIMS OF THE STUDY}

The main goal of this research was to explore the roles of gender identity and gender-role attitudes in predicting attitudes towards same-sex parental rights. As non-normative sexual orientations question the traditional binary and hierarchically organised image of men-women relations, we expected that participants who identified themselves more with their gender, as well as those who held more traditional attitudes toward gender roles, would show more negative attitudes towards samesex parental rights. Additionally, we wanted to explore whether socio-demographic variables such as gender, age, education, religiosity, and political orientation, that proved to be relevant for predicting homonegativity, would also be relevant to predicting attitudes towards same-sex parenting. Finally, we explored whether gender identity and gender-role attitudes bore an effect on attitudes towards same-sex parenting after controlling for socio-demographic variables. 


\section{METHOD}

\subsection{Procedure}

The survey was conducted online (via SurveyMonkey) during the spring of 2014. Participants were recruited by the snowball method. The invitation to take part in the research was sent out through the authors' and their psychology students' personal contacts and social networks to a large number of email addresses. Those who received the invitation were also asked to forward the email to their friends and acquaintances. Participants were informed of the purpose of the study, guaranteed anonymity and were told that the data would be used solely as a collective dataset and for scholarly purposes. At the end of the questionnaire, a contact email address for additional information was provided.

\subsection{Participants}

The total number of participants was 1,162. Those who stated that they were homosexual or bisexual were excluded from the sample (3.8\%). Given the research aims, we have also excluded those who stated that they were not exclusively heterosexual (10.8\%). The final sample thus comprised 992 persons of exclusively heterosexual orientation, with a larger proportion of women (70.5\%) than men $(29.5 \%)$. The age range was 18 to 79 , with the average age of 34.5 years (SD = 11.71). The proportion of older participants $(>55)$ was considerably smaller $(6.3 \%)$ than the proportion of middle-aged (30 to 55 years; $45.7 \%$ ) and younger participants $(<30 ; 48 \%)$. Most of the participants $(79.9 \%)$ had a college degree. The majority of the participants was employed (62.5\%), assessed their socio-economic status as average or above-average (61.4\%) and lived in urban areas (87.5\%). Among those living in urban areas, $59.4 \%$ lived in the capital of Zagreb. About a quarter of participants (23.5\%) spent their youth in rural areas. Around a third of them grew up in large towns (36.4\%), while $40 \%$ grew up in Zagreb. Nearly half of the participants were married or cohabitating $(44.3 \%)$ and $36.6 \%$ had children.

\subsection{Measures}

The Gender Identity scale was constructed for this research. It was based on the Four-Item Social Identification measure (FISI; Postmes, Haslam and Jans, 2013). FISI is a measure of social identification, defined as the positive emotional valuation of the relationship between self and in-group, composed of items adapted from measures by Doosje, Ellemers and Spears (1995) as well as Leach et al. (2008). 
We added two more items to the measure and applied it in two versions, for men and women. On a scale from 1 (strongly disagree) to 5 (strongly agree) participants expressed their gender identification on items such as "I identify with other men/ women" and "Being a man/woman is an important part of how I see myself". The gender identity scale was one-dimensional for both men and women (around 46\% of variance explained) and had high reliability $\left(\alpha_{\text {men }}=.90 ; \alpha_{\text {women }}=.89\right)$. A total score was computed as a linear combination of answers on all six items, with higher results meaning stronger gender identification.

The Attitudes towards Gender Roles scale (ATGR; Kamenov, Jugović and Jelić, 2009, in Kamenov, 2011) is a 23-item Likert-type scale designed to measure attitudes towards gender roles in various aspects of life (family, parenting, education, work, politics, etc.). Participants reported their answers on items such as "A husband and wife should equally divide all the house chores" and "The most important decisions in a family should be made by the husband" on a scale ranging from 1 (strongly disagree) to 5 (strongly agree). After recoding the traditionally formulated items, answers on all the items were added. The ATGR scale proved to be one-dimensional and highly reliable (Cronbach's $\alpha=.92$ ).

Attitudes towards gay/lesbian parental rights scales used in this research were short 2- and 3-item measures adopted from the Attitudes towards Gay/Lesbian Civil Rights Scale (Huić, Jugović and Kamenov, 2015). The attitude towards gay parental rights was measured with the following two items: "I would not allow a gay man to adopt a child" and "Gay men should be allowed to adopt the biological child of their partner". The attitude towards lesbian parental rights was measured with the equivalent two items accompanied by the following third item: "Lesbian women should not be allowed to become mothers through assisted reproduction procedures". On both measures, participants reported on a scale from 1 (strongly disagree) to 5 (strongly agree). The results were coded so that a higher overall result reflected a more positive attitude. Although brief, the measures had good reliability (for the Attitude towards Gay Parental Rights scale, Cronbach's $\alpha$ was .76, $r=.63$; for the Attitude towards Lesbian Parental Rights scale, Cronbach's $\alpha=.81$ ).

The socio-demographic measures included gender (man or woman), age, sexual orientation (a 5-point scale ranging from exclusively heterosexual to exclusively homosexual), marital status (single, married and cohabitation), parental status (no children and with child(ren)), education, socio-economic and work status, size of the settlement they grew up in and they currently live in. In addition, we asked the participants to assess the importance of religion in their lives on a scale ranging from 1 (not important to me at all) to 7 (very important to me) and to indicate their political orientation on a left-right scale $(0=$ left, $5=$ centre, $10=$ right $)$. 
Participants first filled out the Gender Identity scale, followed by the Attitudes towards Gender Roles scale and the Attitudes towards Gay/Lesbian Civil Rights Scale (the order of the two versions was randomised). They answered the demographic questions at the end of the questionnaire. On average, participants needed around 10 minutes to complete the questionnaire.

\section{RESULTS}

Preliminary descriptive analyses showed that our participants moderately identified with their gender and that they expressed relatively egalitarian attitudes towards gender roles (Table 1). Furthermore, they had neutral to mildly positive attitudes towards the parental rights of gays and lesbians, with attitudes being more positive towards lesbian than gay parental rights $(t=5.99, p<.001$; Cohen's $d=0.39)$.

Table 1. Descriptives and gender differences in the study variables

\begin{tabular}{lcccccc}
\hline & \multicolumn{2}{c}{ Men $(\mathrm{n}=294)$} & \multicolumn{2}{c}{ Women $(\mathrm{n}=703)$} & \multirow{2}{*}{ t-test } & Cohen's d \\
& $\mathrm{M}$ & $\mathrm{SD}$ & $\mathrm{M}$ & $\mathrm{SD}$ & & \\
\hline $\begin{array}{l}\text { Gender identity } \\
\begin{array}{l}\text { Egalitarian gender-role } \\
\text { attitudes }\end{array}\end{array}$ & 3.54 & 0.66 & 3.83 & 0.63 & $6.91^{*}$ & 0.45 \\
$\begin{array}{l}\text { Attitude towards gay } \\
\text { parental rights }\end{array}$ & 2.97 & 0.70 & 4.69 & 0.38 & $11.67^{*}$ & 0.68 \\
$\begin{array}{l}\text { Attitude towards } \\
\text { lesbian parental rights }\end{array}$ & 3.16 & 1.49 & 3.40 & 1.44 & $4.29^{*}$ & 0.28 \\
\hline
\end{tabular}

${ }^{*} p<.01$

Compared to men, women identified more with their gender, had more egalitarian attitudes towards gender roles and expressed more positive attitudes towards both gay and lesbian parental rights. These differences were small to moderate in size.

Zero-order correlations between the variables were mostly in accordance with our expectations, although there were some interesting differences between the correlation patterns for men and women (Table 2). For all participants, attitudes towards gay and lesbian parental rights were highly inter-correlated, which is expected and reflects a high degree of correspondence between the level of an individual's openness and willingness to support the parental rights of gays and lesbians. Both these attitudes are associated with marital status, the importance of religion in one's life, political orientation, gender identification, and gender-role attitudes. 
Participants' age and level of formal education were not correlated with these attitudes, and parental status proved to be relevant only for men's attitudes. Gender identification was positively associated with higher religiosity and more right political orientation in both men and women. For women, it is also positively related to their parental status, while for men to their younger age and marital status. Interestingly, the gender identification of women was not related to their attitudes about gender roles, while men who identified more with their gender showed less egalitarian gender-role attitudes. In line with this, men's gender-role attitudes were associated with the same variables as their gender identity, but in the opposite direction. For women, on the other hand, gender identity and parental status were not associated with their attitudes towards gender roles and they showed more egalitarian attitudes as they were older, more educated, lived in a less traditional form of partner relationship, were less religious and less politically right-oriented.

Next, we conducted two separate hierarchical regression analyses ${ }^{1}$ in order to test whether socio-demographic variables such as gender, age, education, religiosity and political orientation predicted attitudes towards gay and lesbian parental rights. Since we were interested in whether, after controlling for these variables, gender identity and gender-role attitudes would explain the additional significant variance of attitudes towards same-sex parental rights, we included these two variables in the second step of the analyses (Table 3).

Separate hierarchical regression analyses for men and women were conducted to assess whether they would reveal additional gender-specific information in predicting attitudes towards same-sex parental rights. As no marked differences were observed both in terms of significant predictors and variance explained, only the results for the entire sample are presented here. 


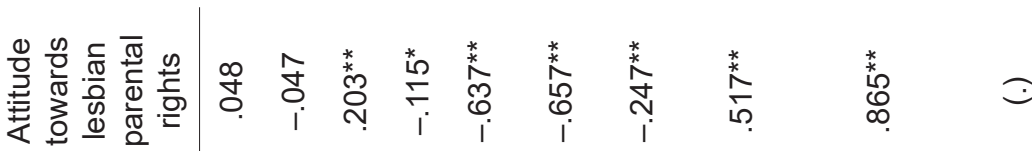

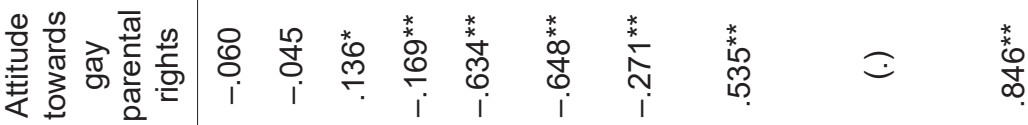

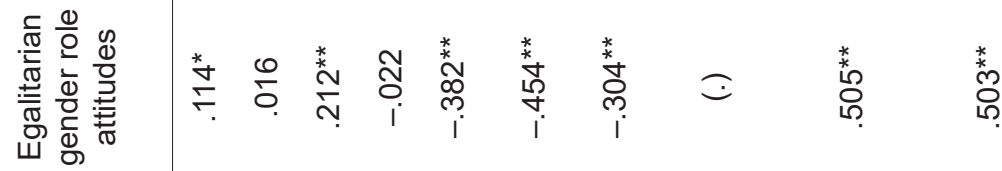

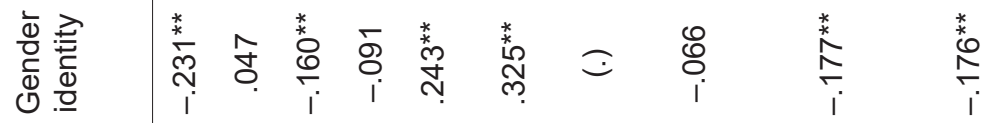

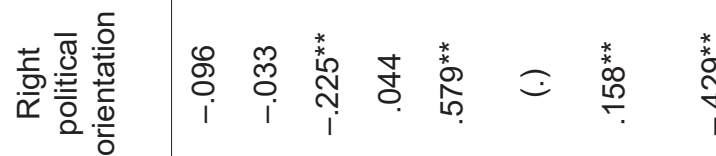

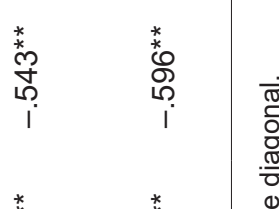

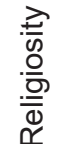

กิ

$\underset{\substack{i \\ \text { in }}}{\stackrel{*}{*}}$

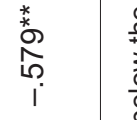

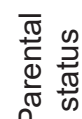

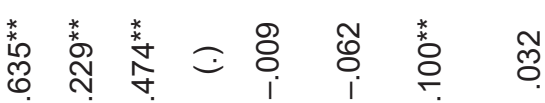

o̊

บับ

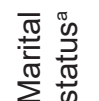

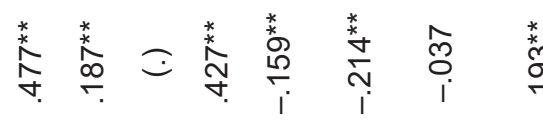

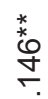

$\stackrel{\text { * }}{\stackrel{*}{\infty}}$

흘

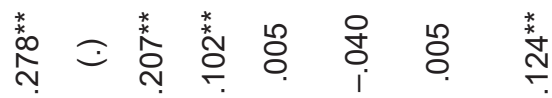

5

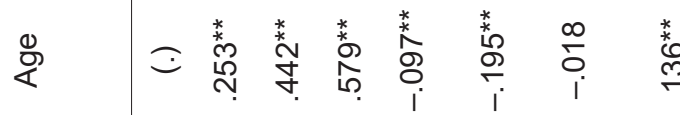

\&

$\infty$

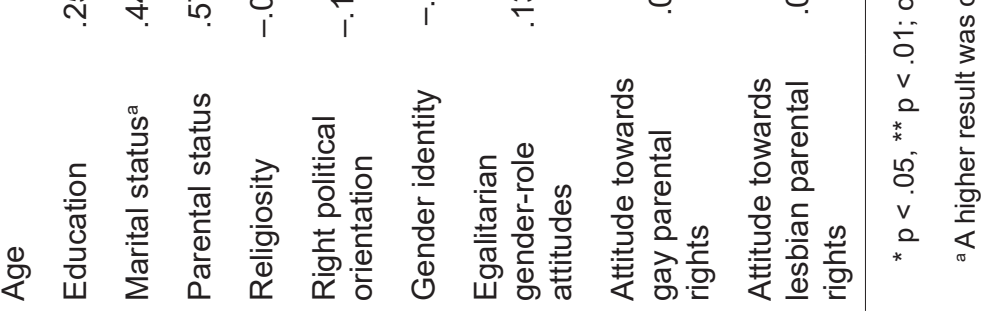


Table 3. Hierarchical regression analyses with attitudes towards gay and lesbian parental rights as outcomes

\begin{tabular}{|c|c|c|c|}
\hline Model & Predictors & $\begin{array}{l}\text { Attitude towards gay } \\
\text { parental rights }\end{array}$ & $\begin{array}{l}\text { Attitude towards } \\
\text { lesbian parental rights }\end{array}$ \\
\hline \multirow[t]{11}{*}{1} & & $\beta$ & $\beta$ \\
\hline & Gender $(M=1, F=2)$ & $.131^{* *}$ & $.118^{* *}$ \\
\hline & Age & -.040 & -.030 \\
\hline & Education & .031 & .012 \\
\hline & $\begin{array}{l}\text { Marital status }(\text { Single }=1 \\
\text { Married }=2, \text { Cohabitating }=3 \text { ) }\end{array}$ & $.063^{*}$ & $.093^{* *}$ \\
\hline & $\begin{array}{l}\text { Parental status }(\text { No children }= \\
1, \text { Child }(\text { ren })=2)\end{array}$ & $-.097^{* *}$ & $-.110^{* *}$ \\
\hline & Religiosity & $-.401^{\star *}$ & $-.373^{* \star}$ \\
\hline & Right political orientation & $-.347^{* *}$ & $-.394^{* *}$ \\
\hline & & $\mathrm{R}=.690^{\star *}$ & $\mathrm{R}=.716^{* *}$ \\
\hline & & $\mathrm{R}^{2}=.476^{* *}$ & $\mathrm{R}^{2}=.513^{* *}$ \\
\hline & & $F=99.69^{* *}$ & $F=117.79^{* *}$ \\
\hline \multirow[t]{14}{*}{2} & & $\beta$ & $\beta$ \\
\hline & Gender $(\mathrm{M}=1, \mathrm{~F}=2)$ & $.059^{*}$ & $.054^{*}$ \\
\hline & Age & -.054 & -.041 \\
\hline & Education & .017 & .001 \\
\hline & $\begin{array}{l}\text { Marital status }(\text { Single }=1 \\
\text { Married }=2, \text { Cohabitating }=3)\end{array}$ & .039 & $.073^{* *}$ \\
\hline & $\begin{array}{l}\text { Parental status }(\text { No children }= \\
1, \text { Child(ren) }=2)\end{array}$ & $-.075^{*}$ & $-.091^{* *}$ \\
\hline & Religiosity & $-.344^{\star *}$ & $-.326^{* *}$ \\
\hline & Right political orientation & $-.271^{* *}$ & $-.330^{* *}$ \\
\hline & Gender identity & -.039 & -.021 \\
\hline & $\begin{array}{l}\text { Egalitarian gender-role } \\
\text { attitudes }\end{array}$ & $.252^{\star *}$ & $.220^{\star *}$ \\
\hline & & $\mathrm{R}=.721^{* *}$ & $\mathrm{R}=.739^{* *}$ \\
\hline & & $\mathrm{R}^{2}=.521^{* *}$ & $\mathrm{R}^{2}=.546^{\star *}$ \\
\hline & & $\mathrm{F}=34.41^{* *}$ & $F=26.15^{\star *}$ \\
\hline & & $\Delta \mathrm{R}^{2}=.045^{\star *}$ & $\Delta \mathrm{R}^{2}=.033^{* *}$ \\
\hline
\end{tabular}

${ }^{*} p<.05,{ }^{* *} p<.01$ 
The socio-demographic variables included in this study alone accounted for $48 \%$ of the attitudes towards gay parental rights and $51 \%$ of the attitudes towards lesbian parental rights variance. In the first step, the contribution of all the variables except age and level of formal education was significant. Women, those who cohabitated, did not have children, were less religious and politically more left-oriented were more likely to report positive attitudes towards both gay and lesbian parental rights. Adding gender identity and attitudes toward gender roles explained additional $4.5 \%$ of the attitudes towards gay parental rights and $3.3 \%$ of the attitudes towards lesbian parental rights. For both outcomes, only gender-role attitudes proved to be significant predictors. More egalitarian attitudes towards gender roles predicted more positive attitudes towards both gay and lesbian parental rights. The entire model explained a total of $52 \%$ of the attitudes toward gay parental rights variance and $55 \%$ of the attitudes towards lesbian parental rights variance.

\section{DISCUSSION AND CONCLUSION}

This study confirmed our initial expectations about the importance of one's attitudes towards gender roles as well as a number of socio-demographic characteristics for the way he or she feels about gays' and lesbians' rights to become parents. More specifically, it showed that people who are more prone to denying these rights to gay men and lesbian women are more likely to be men than women, their religion plays a more important role in their life, they endorse a more right political orientation, they are more likely to cohabitate than to be single or legally married, more likely to be parents themselves and they express more traditional attitudes towards gender roles. On the other hand, age and education, as well as gender identity, did not show to be relevant.

It is interesting to note that age was not a significant predictor. Older persons are generally more rigid in their beliefs and tend to have more negative attitudes towards out-groups. Additionally, they grew up and formed their attitudes at a time when homosexuality was openly prohibited, which is not the case nowadays (Gerhards, 2010; Hellevik, 2002; Jäckle and Wenzelburger, 2015; Kuntz et al., 2015). However, it seems that the effect of age is complex, so that age is not directly affecting the attitudes, but is acting through some mediating variables. It should be noted that, at the level of bivariate correlations, age was not related to attitudes towards same-sex parental rights either, although it was related to all the other variables that proved to be significant determinants of attitudes towards same-sex parental rights. This confirms the relevance of simultaneously testing the effects of socio-demographic characteristics in order to reach more precise conclusions. 
Contrary to our expectations, the level of education was also not a statistically significant predictor of nor did it correlate with attitudes towards same-sex parental rights at the bivariate level. Education is generally associated with critical thinking and lesser susceptibility to conformism, which makes it a factor that promotes tolerance towards all minority groups, including homosexuals (Ohlander, Batalova and Treas, 2005). However, we assessed only the level of formal education, and the topic of homosexual orientation and the rights of LGB people is not addressed throughout formal education in Croatian society. It is still a taboo in our schools and students are not formally educated about the facts of homosexuality and its origin. People gather most of the information through the media and informal education in the family, church or among their friends and acquaintances (Kuliš and Petrović, 2018; Matković, 2018; Novak, 2018; Webb et al., 2017). In other words, the ways of gathering information are not primarily related to the formal level of education, but more to the normative way of thinking within society as well as one's family and referent social groups. Future research ought to address this potential explanation in more detail. Of course, both age and educational level may not have proven related to same-sex parental rights in part due to the restricted variance of those variables in our study (our sample mostly included highly educated participants and a small portion of elderly individuals).

As in the case of determinants of attitudes towards gays and lesbians (Schwartz, 2010), we found that self-reported importance of religion in one's life and political orientation were the most important predictors of attitudes towards gays' and lesbians' parental rights. Homosexuality is opposed to the values promoted by most religions and homosexuals are condemned for breaching these traditional norms (Whitley, 2009). It is thus not surprising that the role of religion is reflected in a lesser willingness to allow gays and lesbians to become parents. Furthermore, more right-wing political options, which are characterised by a conservative, traditionalist value ideology, often openly advocate the suppression of equal rights for homosexually oriented citizens. In less extreme cases, they maintain the existing social status quo by not passing the legislation and stalling decisions that concern the status of sexual minorities, focussing on other issues they perceive as more important for the well-being of the majority (Gerhards, 2010; Inglehart and Baker, 2000; Kuntz et al., 2015). Additionally, gays and lesbians are perceived as a particular threat to traditional family values and traditional gender roles (Kite and Whitley, 1996; Whitley, 2001). The importance of this ideology is confirmed by Goodman and Moradi (2008), who found that the acceptance of the traditional gender ideology is correlated with a greater propensity to discriminate and a lesser inclination towards positive behaviours towards gays and lesbians. This same type of gender traditionalism is also correlated with right-wing conservative political options, which further explains our findings (Whitehead, 2018). 
The main goal of our study was to investigate whether the traditional gender ideology predicted attitudes toward same-sex parental rights above socio-demographic predictors. The results support our expectation about traditional gender norms being negatively associated with peoples' attitudes towards same-sex parental rights. This finding provides evidence that same-sex parents may be evaluated more negatively when traditional gender roles are evaluated positively, indicating a perception that same-sex parents do not conform to gender norms. In other words, it seems that people who hold traditional beliefs about gender roles still find it important for children to have male and female role models in their upbringing, something that same-sex parents do not provide.

These findings are in line with recent studies conducted in Australia (Webb et al., 2017) and in Italy (loverno et al., 2019). Because of this link between traditional gender roles and negative attitudes toward same-sex parenting, it is not surprising that conservative organisations' campaigns all over the world have a good reception among right-wing oriented people with traditional beliefs about the relationship between men and women. By defining same-sex parenting as a threat to the natural order of gender, conservative individuals can justify their negative attitudes towards same-sex parenting while at the same time avoid politically incorrect homophobic language (Baiocco and loverno, 2016).

People who believe in traditional gender roles are also more prone to the belief that homosexuals and heterosexuals are fundamentally different (Haslam and Levy, 2006; Hegarty, 2002). Believing that members of two social categories are fundamentally different and should stay within the boundaries of their own groups creates an especially fertile ground for prejudice against out-group members. Previous studies showed this way of thinking was related to more negative attitudes towards gay men and lesbians (Haslam and Levy, 2006; Hegarty, 2002; Huić, Jelić and Kamenov, 2018). Our study confirmed this and further showed that traditional attitudes towards gender roles, combined with characteristics that imply endorsing "traditional family values" basically divide the social world into "us" and "them", thus creating a fertile ground for discrimination and decreasing the likelihood of promoting equal rights for same-sex couples.

However, contrary to our expectations, gender identification did not prove to be a significant predictor of attitudes towards same-sex parental rights although it was - expectedly - negatively related to those attitudes at the bivariate level. There are at least two possible explanations for these findings. Firstly, both in men and women, gender identity was positively related to the other two variables that proved to be highly related to attitudes towards same-sex parental rights - religiosity and more right political orientation. This may have suppressed the multivariate association between gender identity and same-sex parental rights. Secondly, these results 
may reflect the complexity of gender identity, especially for women. A recent study by Van Breen and her colleagues (2017) proposed that women's attitudes towards gender group membership were governed by two largely orthogonal dimensions of gender identity: identification with women and identification with feminists. Different combinations of high vs low identification with women and feminists can be thought of as reflecting four theoretical identity "types" and offer a new perspective on gender identity. A series of four studies by Van Breen et al. (2017) showed how the multiple identity approach predicts distinct attitudes towards gender issues, with gender stereotypes being among them. As our findings showed that women's gender identification was not related to their attitudes towards gender roles, we could hypothesise that this complex identity is for some women positively, and for others negatively associated with gendered roles and egalitarian attitudes. Future research should explore this approach to gender identity in more detail.

We should mention the methodological limitations of this research, some of which have already been touched upon. Our results were acquired using a correlation design with an online convenience sample. Firstly, the design does not allow for a causal interpretation of our findings. Only future experimental or longitudinal research can provide an account of the direction of the causal link. Secondly, we rely on self-report data, which is especially important to consider when participants are impelled to provide politically correct responses. However, we have not observed overly positive attitudes towards gays and lesbians and their parental rights. There may be evidence that impression management is not associated either with attitudes towards gays and lesbians or with the willingness to discriminate against them (Goodman and Moradi, 2008). Furthermore, our findings cannot be generalised to the national population. In addition to being non-probabilistic, our sample is disproportionately composed of individuals whose characteristics, as found in existing research, make them more likely to have positive attitudes towards gays and lesbians, and thus less likely to discriminate against them. It should also be noted that our sample is nevertheless relatively heterogeneous with regard to a number of socio-demographic characteristics. Additionally, it is a sample of adults rather than students, who tend to be the target population of much of the similar research.

Notwithstanding these limitations, our study still provides valuable information concerning the antecedents of the way people in Croatian society think and feel about the right of same-sex couples to become parents. We provided a simultaneous test of the role of various socio-demographic characteristics confirming that gender, religiosity, and political orientation are important correlates not just of attitudes towards homosexuals in general, as shown in previous studies (e.g. Brewer, 2003; Gelbal and Duyan, 2006; Herek, 2002; Huić, Jelić and Kamenov, 2018; Huić, Jugović and Kamenov, 2015; Jugović and Ančić, 2013; Kite and Whitley, 1996; 
LaMar and Kite, 1998; Olson, Cadge and Harrison, 2006; Whitley, 2009; Wood and Bartkowski, 2004), but of the attitudes towards their parental rights as well, while age and level of formal education are not. Additionally, we provided evidence about the role of individuals' values and experiences regarding intimate relationships and family life in predicting these attitudes. This wide-ranging approach to examining the predictors of attitudes toward same-sex couples' parental rights, such as socio-demographic characteristics and gender ideology, made it possible to control for their roles and to contribute to the scientific study of the determinants of the willingness to discriminate against gays and lesbians concerning their parental rights. It is noteworthy that our models explained more than $50 \%$ of the variance of our outcomes.

Finally, what are the implications of our results? The findings may be received as a call for action to the government, as well as policy and opinion makers in Croatia, to put more effort in creating a society with equal rights for all its members. Questioning same-sex parental rights at the society level allows citizens to rely on their personal attitudes and values, rationalising their willingness to discriminate against gays and lesbians with the notion that they would not be adequate role models for their children or with the fear that children of same-sex parents would be stigmatised. When equal rights are institutionalised, as it could be the case with the rights of same-sex couples to provide foster care, adopt children and become parents by assisted reproductive technology use, members of society get a clear message that same-sex couples and their children are accepted and should be treated as equals (Adamczyk and Pitt, 2009; Gerhards, 2010; Jäckle and Wenzelburger, 2015; Kuntz et al., 2015). In other words, full institutional recognition reduces the structural stigma of homosexually oriented persons and their children, reduces the level of stress they have to cope with as a minority (Meyer, 2003) and has a positive impact on their functioning and mental health (Jugović, Pikić and Bokan, 2006; Kamenov, Huić and Jelić, 2015; Kamenov, Jelić and Huić, 2016; Maričić et al., 2016; Takács and Szalma, 2013).

\section{REFERENCES}

Adamczyk A and Pitt P (2009). Shaping attitudes about homosexuality: The role of religion and cultural context, Social Science Research, 38 (2): 338-352. https://doi.org/10.1016/j. ssresearch.2009.01.002

Avery A, Chase J, Johansson L, Litvak S, Montero D and Wydra M (2007). America's changing attitudes toward homosexuality, civil unions, and same gender marriage, Social Work, 52 (1): 71-79. https://doi.org/10.1093/sw/52.1.71 
Baiocco R and loverno S (2016). Same-Sex Parenting and Children Wellbeing: Gender Identity or Gender Ideology Confusion?, Giornale Italiano Di Psicologia, 43 (1-2): 85-88. https://doi.org/10.1421/83620

Bartolac A, Kamenov Ž and Petrak O (2011). Rodne razlike u obiteljskim ulogama, zadovoljstvu i doživljaju pravednosti s obzirom na tradicionalnost stava [Gender differences in family roles, satisfaction and perception of equity with regard to the traditionality of gender attitudes], Revija za socijalnu politiku, 18 (2): 175-194. https:// doi.org/10.3935/rsp.v18i2.998

Brewer PR (2003). Values, political knowledge, and public opinion about gay rights, Public Opinion Quarterly, 67 (2): 173-201. https://doi.org/10.1086/374397

Crowl A, Ahn S and Baker J (2008). A meta-analysis of developmental outcomes for children of same-sex and heterosexual parents, Journal of GLBT Family Studies, 4 (3): 385-407. https://doi.org/10.1080/15504280802177615

Davies M (2004). Correlates of negative attitudes toward gay men: Sexism, male role norms, and male sexuality, Journal of Sex Research, 41 (3): 259-266. https://doi. org/10.1080/00224490409552233

Doosje B, Ellemers N and Spears R (1995). Perceived intragroup variability as a function of group status and identification, Journal of Experimental Social Psychology, 31 (5): 410-436. https://doi.org/10.1006/jesp.1995.1018

Eagly A (1987). Sex differences in social behavior: A social role interpretation. Hillsdale: Erlbaum. https://doi.org/10.4324/9780203781906

Gelbal S and Duyan V (2006). Attitudes of university students toward lesbians and gay men in Turkey, Sex Roles, 55 (7-8): 573-579. https://doi.org/10.1007/s11199-006-9112-1

Gerhards J (2010). Non-discrimination to homosexuality: The European Union's policy and citizens' attitudes to homosexuality in 27 European countries, International Sociology, 25 (1): 5-28. https://doi.org/10.1177/0268580909346704

Goodman MB and Moradi B (2008). Attitudes and behaviors toward lesbian and gay persons: Critical correlates and mediated relations, Journal of Counseling Psychology, 55 (3): 371-384. https://doi.org/10.1037/0022-0167.55.3.371

Grapes K (2006). Ignorant discrimination: How education levels affect attitudes toward homosexuality and gay rights, Sociological Viewpoints, 22: 51-59.

Haslam N and Levy SR (2006). Essentialist beliefs about homosexuality: Structure and implications for prejudice, Personality and Social Psychology Bulletin, 32 (4): 471-485. https://doi.org/10.1177/0146167205276516

Hegarty P (2002). "It's not a choice, it's the way we're built": Symbolic beliefs about sexual orientation in the US and Britain, Journal of Community \& Applied Social Psychology, 12 (3): 153-166. https://doi.org/10.1002/casp.669

Hellevik O (2002) "Age Differences in Value Orientation: Life Cycle or Cohort Effects?", International Journal of Public Opinion Research 14 (3): 286-302. https://doi.org/10.1093/ ijpor/14.3.286

Herek GM (1984). Beyond "homophobia": A social psychological perspective on attitudes toward lesbians and gay men, Journal of Homosexuality, 10 (1-2): 1-21. https://doi. org/10.1300/J082v10n01_01

Herek GM (1988). Heterosexuals' attitudes toward lesbians and gay men: Correlates and gender differences, The Journal of Sex Research, 24 (4): 451-477. https://doi. org/10.1080/00224498809551476 
Herek GM (2002). Gender gaps in public opinion about lesbians and gay men, Public Opinion Quarterly, 66 (1): 40-66. https://doi.org/10.1086/338409

Herek GM and McLemore KA (2013). Sexual prejudice, Annual Review of Psychology, 64: 309-333. https://doi.org/10.1146/annurev-psych-113011-143826

Hicks S (2008). Gender role models... who needs 'em?!, Qualitative Social Work, 7 (1): 43-59. https://doi.org/10.1177/1473325007086415

Huić A, Jelić M and Kamenov Ž (2015). What predicts the willingness of heterosexual persons to behave in a positive or negative manner towards homosexual persons?, Kriminologija i socijalna integracija, 23 (2): 110-141.

Huić A, Jelić M and Kamenov Ž (2018). Essentialist beliefs about homosexuality predict positive and negative behavioral intentions toward lesbian women and gay men, Journal of Homosexuality, 65 (12): 1631-1655. https://doi.org/10.1080/00918369.2017.1383104

Huić A, Jugović I and Kamenov Ž (2015). Stavovi studenata o pravima osoba homoseksualne orijentacije [Students' attitudes towards the rights of homosexual persons], Revija za socijalnu politiku, 22 (2): 219-244. https://doi.org/10.3935/rsp.v22i2.1224

Inglehart R and Baker WE (2000). Modernization, cultural change, and the persistence of traditional values, American Sociological Review, 65 (1): 19-51. https://doi. org/10.2307/2657288

ILGA Europe (2019). Annual Review of the Human Rights Situation of Lesbian, Gay, Bisexual, Trans, and Intersex People in Croatia Covering the Period of January to December 2018. https://www.ilga-europe.org/sites/default/files/croatia.pdf (28 July 2019)

loverno S, Baiocco R, Lingiardi V, Verrastro V, D’Amore S and Green RJ (2019). Attitudes towards same-sex parenting in Italy: The influence of traditional gender ideology, Culture, Health \& Sexuality, 21 (2): 188-204. https://doi.org/10.1080/13691058.2018.1459846

Jäckle S and Wenzelburger G (2015). Religion, Religiosity, and the Attitudes Toward Homosexuality - A Multilevel Analysis of 79 Countries, Journal of Homosexuality, 62 (2): 207-241. https://doi.org/10.1080/00918369.2014.969071

Jugović I and Ančić B (2013). Effects of religiosity and spirituality on gender roles and homonegativity in Croatia and Slovenia. In: Furlan Štante N and Harcet M (eds). Spirituality of Balkan women breaking boundaries: The voices of women of ex-Yugoslavia. Koper: Univerzitetna založba Annales, 91-115.

Jugović I, Pikić A and Bokan N (2006). Lesbians, gays and bisexuals in Croatia: How the stigma shapes lives. In: Kuhar R and Takacs J (eds). Beyond the pink curtain: Everyday life of LGBT people in Eastern Europe. Ljubljana: Peace Institute, 345-363.

Kamenov Ž (2011). Stavovi, predrasude i uvjerenja o uzrocima rodne diskriminacije [Attitudes, prejudice and beliefs about causes of gender discrimination]. In: Kamenov Ž and Galić B (eds). Rodna ravnopravnost i diskriminacija u Hrvatskoj [Gender equality and discrimination in Croatia]. Zagreb: Ured za ravnopravnost spolova, 92-111.

Kamenov Ž, Huić A and Jelić M (2015). Minority stress and mental health of homosexual and bisexual men and women: A review of research on the minority stress model from a Croatian perspective, Kriminologija i socijalna integracija, 23 (2): 40-78.

Kamenov Ž, Jelić M and Huić A (2016). Problemi i izazovi seksualnih manjina u Hrvatskoj [Sexual minorities in Croatia: Problems and challenges]. Zagreb: FF Press.

Kite ME and Deaux K (1987). Gender Belief Systems: Homosexuality and the Implicit Inversion Theory, Psychology of Women Quarterly, 11 (1): 83-96. https://doi. org/10.1177/0146167296224002 
Kite ME and Whitley BE (1996). Sex differences in attitudes toward homosexual persons, behaviors, and civil rights: A meta-analysis, Personality and Social Psychology Bulletin, 22 (4): 336-353.

Kuliš I and Petrović D (2018). Istraživanje povezanosti nekih obrazovnih faktora i stavova srednjoškolaca o osobama homoseksualne orijentacije [Exploring the relations between some educational factors and highschool students' attitudes towards homosexual persons], Psyche, 1 (1): 9-16.

Kuntz A, Davidov E, Schwartz SH and Schmidt P (2015). Human values, legal regulation, and approval of homosexuality in Europe: A cross-country comparison, European Journal of Social Psychology, 45 (1): 120-134. https://doi.org/10.1002/ejsp.2068

LaMar L and Kite M (1998). Sex differences in attitudes toward gay men and lesbians: A multidimensional perspective, Journal of Sex Research, 35 (2): 189-196. https://doi. org/10.1080/00224499809551932

Leach CW, van Zomeren M, Zebel S, Vliek MLW, Pennekamp SF, Doosje B, Ouwerkerk JW and Spears R (2008). Group-level self-definition and self-investment: A hierarchical (multicomponent) model of in-group identification, Journal of Personality and Social Psychology, 95 (1): 144-165. https://doi.org/10.1037/0022-3514.95.1.144

Lehavot K and Lambert AJ (2007). Toward a greater understanding of antigay prejudice: On the role of sexual orientation and gender role violation, Basic and Applied Social Psychology, 29 (3): 279-292. https://doi.org/10.1080/01973530701503390

Ljubičić V (2015). Iskustva Pravobraniteljice za ravnopravnost spolova u suzbijanju homofobije [The experience of the Ombudsperson for Gender Equality in combating Homophobia], Kriminologija i socijalna integracija, 23 (2): 253-281.

Maričić A, Štambuk M, Tadić Vujčić M and Tolić S (2016). Ja nisam gej mama, ja sam mama: roditeljstvo LGB osoba u Hrvatskoj [I'm not a gay mom, I'm a mom. Parenthood of LGB people in Croatia]. Zagreb: Jesenski i Turk.

Matković HG (2018). Znanje srednjoškolaca o homoseksualnoj orijentaciji i sklonost diskriminaciji homoseksualnih osoba [Highschool students' knowledga about the homosexual orientation and willingness to discriminate homosexual persons]. Unpublished master thesis. Zagreb: University of Zagreb.

Meyer IH (2003). Prejudice, social stress, and mental health in lesbian, gay, and bisexual populations: Conceptual issues and research evidence, Psychological Bulletin, 129 (5): 674-697. https://doi.org/10.1037/0033-2909.129.5.674

Novak P (2018). Stavovi srednjoškolaca prema osobama homoseksualne orijentacije $i$ njihova povezanost s vršnjačkim i roditeljskim normama [Highschool students' attitudes towards homosexual persons and their associations with peers' and parents' norms]. Unpublished master thesis. Zagreb: University of Zagreb.

Ohlander J, Batalova J and Treas J (2005). Explaining educational influences on attitudes toward homosexual relations, Social Science Research, 34 (4): 781-799. https://doi. org/10.1016/j.ssresearch.2004.12.004

Olson LR, Cadge W and Harrison JT (2006). Religion and public opinion about same-sex marriage, Social Science Quarterly, 87 (2): 340-360. https://doi.org/10.1111/j.15406237.2006.00384.x

Patterson CJ (2005). Lesbian and gay parents and their children: Summary of research findings. In: Harper GW (ed.). Lesbian and gay parenting: A resource for psychologists. Washington: American Psychological Association, 5-79. 
Postmes T, Haslam SA and Jans L (2013). A single-item measure of social identification: Reliability, validity and utility, British Journal of Social Psychology, 52 (4): 597-617. https://doi.org/10.1111/bjso.12006

Reese G, Steffens M and Jonas KJ (2013). Religious affiliations and attitudes towards gay men: On the mediating role of masculinity threat, Journal of Community and Applied Social Psychology, 24 (4): 340-355. https://doi.org/10.1002/casp.2169

Same-Sex-Life-Partnership Act (2014). Official Gazette of the Republic of Croatia, 92. http:// www.zivotnopartnerstvo.com/wp-content/uploads/2015/06/same-sex-life-partnershipact-croatia.pdf

Schwartz J (2010). Investigating differences in public support for gay rights issues, Journal of Homosexuality, 57 (6): 748-759. https://doi.org/10.1080/00918369.2010.485875

Šurina M (2012). "Gayevi ne mogu imati ista prava jer mi smo deklarirana katolička zemlja!" ["Gay people cannot have the same rights because we live in country that is declared as catholic!"]. tportal.hr, 11 May. https://www.tportal.hr/vijesti/clanak/gayevi-ne-mogu-imatiista-prava-jer-mi-smo-deklarirana-katolicka-zemlja-20120511 (28 July 2019)

Takács J and Szalma I (2013). How to measure homophobia in an international comparison?, Družboslovne razprave, 29 (73): 11-42.

Turner JC, Hogg MA, Oakes PJ, Reicher SD and Wetherell MS (1987). Rediscovering the Social Group: A self-Categorization Theory. Cambridge: Blackwell.

Van Breen J, Spears R, Kuppens T and de Lemus S (2017). A Multiple Identity Approach to Gender: Identification with Women, Identification with Feminists, and Their Interaction, Frontiers in Psychology, 8: 1019. https://doi.org/10.3389/fpsyg.2017.01019

Vučković Juroš T (2017). Comparing the Outcomes of Children of Same-Sex and Opposite-Sex Partners: Overview of the Quantitative Studies Conducted on Random Representative Samples, Croatian Sociological Review, 47 (1): 65-95. https://doi. org/10.5613/rzs.47.1.3

Webb SN and Chonody JM (2014). Heterosexual attitudes toward same-sex marriage: The influence of attitudes toward same-sex parenting, Journal of GLBT Family Studies, 10 (4): 404-421. https://doi.org/10.1080/1550428X.2013.832644

Webb SN, Chonody JM and Kavanagh PS (2017). Do We Think Children Need a Mom and Dad?: Understanding How Gender Ideology Impact Attitudes Toward Same-sex Parent Family Rights, Journal of Homosexuality, 65 (10): 1351-1371. https://doi.org/10.1080/0 0918369.2017.1374071

Whitehead AL (2018). Homosexuality, Religion, and the Family: The Effects of Religion on Americans' Appraisals of the Parenting Abilities of Same-Sex Couples, Journal of Homosexuality, 65 (1): 42-65. https://doi.org/10.1080/00918369.2017.1310550

Whitley BE (2001). Gender-role variables and attitudes toward homosexuality, Sex Roles, 45 (11-12): 691-721. https://doi.org/10.1023/A:1015640318045

Whitley BE (2009). Religiosity and attitudes toward lesbians and gay men: A metaanalysis, International Journal for the Psychology of Religion, 19 (1): 21-38. https://doi. org/10.1080/10508610802471104

Wood PB and Bartkowski JP (2004): Attribution style and public policy attitudes toward gay rights, Social Science Quarterly, 85 (1): 58-74. https://doi.org/10.1111/j.00384941.2004.08501005.x 


\title{
Stavovi heteroseksualnih osoba u Hrvatskoj prema pravu na roditeljstvo lezbijki i gejeva: efekt tradicionalnog stava prema rodnim ulogama
}

\author{
Željka KAMENOV (D), Aleksandra HUIĆ (D), Margareta JELIĆ \\ Odsjek za psihologiju Filozofskog fakulteta Sveučilišta u Zagrebu, Hrvatska \\ zkamenov@ffzg.hr, ahuic@ffzg.hr, mjelic@ffzg.hr
}

\section{SAŽETAK}

Osnovni cilj istraživanja bio je ispitati ulogu rodnog identiteta i stava prema rodnim ulogama u objašnjavanju stava prema pravu lezbijki i gejeva na roditeljstvo, s obzirom na to da nenormativne seksualne orijentacije dovode u pitanje binarnu i hijerearhijski organiziranu predodžbu odnosa između muškaraca i žena. Dodatni cilj bio je provjeriti jesu li sociodemografske karakteristike koje su se pokazale važnim prediktorima stavova prema homoseksualnim osobama, poput dobi, stupnja obrazovanja, religioznosti i političkog opredjeljenja, također odrednice podržavanja prava gejeva i lezbijki na roditeljstvo te hoće li se rodni identitet i stav prema rodnim ulogama pokazati odrednicama ovog stava i nakon što se njihov utjecaj kontrolira. Istraživanje je provedeno internetskom anketom tijekom proljeća 2014. godine, a u njemu su sudjelovale 992 heteroseksualne osobe iz Hrvatske oba spola ( $70 \%$ žena) u dobi od 18 do 79 godina. Rezultati pokazuju da sudionici/e manje podržavaju roditeljska prava gej muškaraca u odnosu na roditeljska prava lezbijki te da žene imaju pozitivnije stavove nego muškarci prema roditeljskim pravima i gejeva i lezbijki. U skladu s očekivanjima, prava lezbijki i gejeva na roditeljstvo više podržavaju manje religiozne osobe i sudionici lijevog političkog opredjeljenja, kao i sudionici/e koji žive u izvanbračnoj zajednici u odnosu na one u braku. Dob i stupanj obrazovanja nisu se pokazali prediktivnima, ali ni rodni identitet. Pokazalo se, međutim, da, u skladu s očekivanjima, negativniji stav prema pravu na roditeljstvo lezbijki i gejeva imaju osobe s tradicionalnijim stavom prema rodnim ulogama te sudionici/e koji su i sami roditelji.

Ključne riječi: stavovi o pravu na roditeljstvo gejeva i lezbijki, rodni identitet, stavovi prema rodnim ulogama, hrvatski građani, sociodemografska obilježja 
